\title{
Designing for the homeless in the Product and Industrial Master at FEUP
}

\author{
Daniela Carriço, Bárbara Rangel \\ FEUP, Master in Product and Industrial Design \\ University of Porto \\ Porto, Portugal
}

Abstract - This Paper intends to describe the development of a product design project with the aim to promote social integration and increase the self-esteem of a population living in a homeless situation.

In 20134.420 persons lived on the street in Portugal. Now this is the number of people being helped by the Social Security Institute. This institution helps the homeless through a social monitoring providing them a temporary accommodation, but the reality it's that in Portugal a person living in poor conditions receives from social insertion income a maximum of 178,15 euros per month. From this amount, 150 euros are immediately spent for the costs of the room, water and electricity. Living with almost nothing their expectations are poor and their self-esteem will be lower and lower, leading to them the possibility to fall into the street again.

The project presented was done for the movement "Uma Vida com a Arte", a movement created by a group of persons that are living in a homeless situation in Porto. This movement was created with the intention to give to the homeless people a voice through the art.

The project was developed with the collaboration of the members of the movement, which allowed us through meetings to be able to understand their necessities and capacity of work. This gave us furthermore the ability to determinate the best product to be held and what work process could be performed for its future development. Since this population have no financial capacity or professional skills, we decided to do an Ecodesign product, made from recycled materials and with simple solutions to be done entirely by hand without the need for professional tools.

With this paper it's intended to show the process since the design idea to its creation, and production and also how the target population was inserted during the project with related results. The aim of this project is to demonstrate how the design can make a difference in the life of people living in extreme poor conditions, and at the same time, reduce waste by using recycle materials.

Keywords—social design; ecodesign; homeless; social business

\section{INTRODUCTION}

Throughout the world people can witness one of the greatest problem that the humanity always faced - the homeless.
Everyday we see people living in the street, sleeping under blankets and cardboards or begging. These people are frequently ignored by the society and consequently the homeless become a part of the street.

The homeless people are persons that once had a job, a family and a house and due to a misfortune in their lives they end up in the streets. What we forget is that they are still persons, they are still able to work and they deserve a chance to have a life.

"Homeless is one of the least understood social issues. The public image of homelessness and public perceptions of the nature and causes of homelessness have little relation of the situation" (Levinson 2004, 20).

This project aims to help the homeless reconstructing their life by giving them work, so they can slowly improve their self-esteem and their conditions.

Taking a motto from Maria Loschiavo "Despite their heroic efforts, the collectors ${ }^{1}$ are not properly recognized by society as a whole, and directly or indirectly they work for someone else and companies often profit from their work. Design could collaborate from different perspectives to change their image so they may be seen as a relevant assets." (Loschiavo dos Santos 2007, 2)

With this paper we intend to demonstrate all phases undertaken for the realization of this project with the hope to inspire future projects.

\section{DESIGN FOR Social CHANGE}

The world where we live in is a world where people give more attention for the last technology or the new fashion trend launched on the market instead of worrying about the emergency that our world faces. Our world is a place where, an infinite number of products are discarded into landfills, where the majority of the global population is living in extreme poor conditions and where people die everyday from hunger. Unfortunately design is one of the major causes of this reality, over the years, design has been used as a way of manipulating people for buying new products on the market.

${ }^{1}$ Collectors - Poor people that collects discards materials for living 
But we believe that together people and design can make a difference. If each person dedicate some time for social improvement, it is possible to reduce poverty. "To sum up, more people today have the freedom, time, wealth, health, exposure, social mobility, and confidence to address social problems in a bold new ways" (Bornstein 2007, 51).

Design must be used for social change, rather for the enrichment of industries, as says Mara Loschiavo, “...there is a need to mobilize the design to gender issues, inequality, insecurity, informality, human poverty." (Globo Universidade 2012, 2)

So, the project described in this paper tries through design give new opportunities for people living in extreme poor conditions. This is a sustainable project that tries to alleviate poverty and at the same time reduce the number of discarded products, by valuing a person's work capacity and giving to the discarded materials a new life.

"Creating opportunities for steady employment at reasonable wages is the best way to eradicate poverty. There is much empirical evidence showing that "creating decent employment opportunities is the best way to take people out of poverty. In addition, there is a strong link between productivity and decent work" (ILO, 2005)" (Karnani 2007, 31).

\section{METHODS}

below:

During this work we followed the steps presented

- Research on topics about social and environmental design. We needed to know more about environmental concerns and the recycling of products. We also needed to know what was already done in the design area to help the homeless.

- Establish contacts with persons from another disciplinary area. We needed someone with a connection with this population.

Identify between the existing organizations for homeless who would have a more need for a design contribution.

Contact with the movement "Uma vida como a Arte" and identify their needs.

Creation of the product and successive tests.

Creation of a Business Plan to give support to the project.

Establish contacts with Adeima, association for integrated development of Matosinhos, extending the project by integrating people unemployed from Matosinhos.

Invite recognized designers and architects to increase the range of products and to give visibility to the project.
Start the designing of eco-design products with first year students from the master of industrial and product design from Oporto University.

\section{BACKGROUND}

This project is inserted in a European project about community service engineering. The main objective of it was to create a new opportunity through design to the local population living in poverty.

Feantsam, the European Federation of European Organizations, who works with homeless, defined them as someone who are: "rooflessness (without a shelter of any kind, sleeping rough); houselessness (with a place to sleep but temporary in institutions or shelter); living in insecure housing (threatened with severe exclusion due to insecure tenancies, eviction, domestic violence); living in inadequate housing (in caravans on illegal campsites, in unfit housing, in extreme overcrowding).” (FEANTSA 2011)

The homeless are persons who fight everyday to live for the next day. Due of their lifestyle they are a bit unpredictable but at the same time they have a great will to work and fight poverty.

In Portugal, by 2013 were registered a total of 4.420 homeless people. Oporto is the city with the highest number of homeless registered in that year with a total of 1300 homeless registered.

Homeless people receive only 178,20 euros per month of social insertion of which, more than half are for the costs of the room, water and electricity.

This project found its way when we met "Uma Vida como a Arte". This movement is formed by a group of people, from Oporto that once lived on the streets, and are now living in a homeless condition. This group tries everyday to fight against the stigma from society who sees homeless people as beggars.

The goal of this movement is to show the population that the homeless people can have value and are willing to work. To achieve this goal, they established meetings every-week in which they discuss the development of the work they have been doing to fight this stigma.

\section{DESIGNING THE PRODUCT}

This project begins with the will to design a product that could give a new meaning to the lives of the homeless.

Through the meetings with "Uma Vida como a Arte" we identified their necessities and capacity of work.

As the name of the movement says "A life as the art" they are artists and express their feelings trough the art. They create products with the aim to show their vision of the city they live in, Oporto. Books of poems and photographs are some of the products developed by them. 
Since they had already some products but didn't had a way to show them, we decided to do an exhibitor where they could place their products and sell them. This exhibitor could be portable or be in a fix position.

The idea to make a portable product appears because of the homeless people lifestyle. Since they normally don't stay long in the same place and they are the ones who best know the city where they live, we establish that the product should be portable. So, this product could be used while they are moving, letting them walk and show the products at the same time. We also decided to make the product with the possibility to have a fixed position, with an additional support to fix to the ground, so they could stay in the same place in a long period of time.

The product is made with recycled materials because there was no financing to the development of it. The materials chosen were Pet Bottles and Tetrapack ${ }^{\circledR}$. These materials were chosen to provide impermeability and resistance.

\section{CReating a Business}

After the conclusion of the product, was needed organize the project in a business model. With the construction of it, was possible to give sense to the project for the sell of the products.

To fill the requirements needed to support the project, professor Luis Cardia guided us to complete the ideal business model.

\section{a) Customer Segments}

The most important sector when starting a business are our buyers. The person who buys the product is the one that allow us to continuing producing. So, we started to identify who were our main customers that could buy our products.

Thus, we identified as our main customers the tourists, for two major reasons. First, because in the past several years the number of tourists in Oporto city has been increasing. Every year Oporto has the privilege to receive more tourists. Second because the products presented by the homeless are a representation of the city of Oporto. These products represent one vision of the city by the eyes of the homeless.

\section{b) Key Partners}

With the customers identification we needed to realize what was the best way to get to them.

In order to make our product known in our public we needed partners in the tourism sector of Oporto. We needed the support from the most important tourist sectors from the city, to make the divulgation of the products - informing their customers about our products and sales location. Thereby, we needed to address the touristic information offices, touristic transports and other touristic spaces from the city.

One major key partner was established to guarantee our business but we also needed partners to support our management costs.
We needed support to financing the workspace, for the materials and for buying the tools needed to work.

Adeima, Association for integrated development of Matosinhos, heard about our project and offered us help. This association has the aim to promote social and economical integration between the poor persons living in Matosinhos. So, in their attempt to restore the lives of people with economical problems, they also faced a problem. Adeima had a number of unemployed persons receiving from social security but that are still able to work. These people are classified persons that had the misfortune to loose their job. Most of these people worked in their previous jobs with different materials, like wood and metals. In order to maintain these people working and keeping them active persons, this association needed to create them an occupation.

So we decided to combine the Matosinhos workers with people living in a homeless situation, in order to take a more stable business. Once homeless people accustomed for many years to live without commitments and obligations have difficulty suddenly have to comply with certain obligations, which they have to attend everyday.

The Matosinhos workers can thus use their skills and make the products while the persons in a homeless situation can sell them on the streets. This way the homeless aren't obligated to have a fixed commitment, allowing them to sell the product when they are ready and predisposed to it.

To make our project possible, Adeima provides us the space where the unemployed can work and they also give us total freedom to buy the tools needed for the products construction.

At last but not least important, we needed partners who provide us the necessary materials for the realization of the products.

Although the products are made entirely of discarded materials, making them free materials, it was necessary to obtain partners to provide us of it.

We find these partners with Lipor and restaurants from Matosinhos.

Lipor, International Waste Management of Porto, is a company that treats waste management, recovery and treatment of municipal waste from Oporto and eight associated municipalities.

Thus, on one hand, the restaurants can provide the discarded products, like glass bottles, plastic bottles, Tetrapack $^{\circledR}$, bottle caps and cork stoppers. On the other hand, Lipor can provide treated material. Through the management of municipal waste, they can provide us materials already transformed in a new material and ready to apply in new products.

\section{c) Channels}

Like it was mentioned before, the main purpose is to sell the products in the streets by the homeless people. These products can be sold everyday in the main streets or in street markets that frequently occur in Oporto. 
The product created for selling the products can also serve as a showcase to easily identify the products from its source. This set can be placed in different stores like tourist information posts and art and design museums shops.

\section{d) New Products}

Planning the business model allow us to make a sustained business and realize all the steps necessary for the creation, production and sale of products.

Thanks to the different partners reached, the project became bigger and with a bigger project we needed to create more products. We felt the need to create a wider range of products, so the customers could have more choosing options and also so it can meet the needs of all people involved in the project.

Therefore, we decided to invite recognized designers and architects to design products with recycled materials. These products will allow us to give greater visibility to the project and at the same time give it more value.

It is also taking place in the first year design class from industrial and product design master the developing of eco-designed products. These products are being made within the context of this project and will be part of the range of products that will be on sale.

Thus, there will be two different categories of products. A category with higher priced products, with design signature, made by architects and designers recognized. Another category will have products with a lower price, consisting of products created by young designers.

\section{PROJECT CONTRIBUTIONS}

The main contributions to this project given to the society include:

- Creating a new occupation for people living in a homeless situation and unemployed. Thus, increasing their self-esteem and enhance their work skills.

- Income generation for people living with no resources.

- Diminish the number of products that end up in a landfill. Thus, new products are created, adding a new value for discarded materials.

- Collaboration between different sectors. Thereby people in homeless conditions, waste management companies and designers work for the same purpose.

- Creating a conscience among students about the role that the designer can have in social and environmental concerns.

- Creating social and environmental concerns for people in general.

\section{VIII.CONCLUSIONS AND FUTURE WORK}

This project was created with the main intention to help the homeless to have a better life.

Throughout the project new requirements have emerged and from the aim to help people living in homeless conditions the project evolved to environmental concerns. Thus, we aimed to create a sustainable business, creating a new occupation for unemployed persons, increase in selfesteem of homeless people and at the same time having in mind the environment.

With the creation of this project we hope to create a new income to the poor people living in Portugal. We intend to create a social and environmental conscious in young designers and with the hope they have this concerns in mind for future projects.

The next step will be to put this business model into practice. First, we will start producing the product that will allow the selling. After the product creation from young designers and recognized designers and architects, we will produce them and sell them.

When people living in the homeless conditions start to sell the products, we would like to add a psychologist into our project. The purpose of the psychologist is to analyze the group of people living in homeless conditions and determinate their social and psychological evolution over time.

\section{REFERENCES}

[1] Bornstein, David. 2007. How to change the world. New York: Oxford University Press

[2] Departamento de Prestações e Contribuições. 2015. "Guia Prático Rendimento Social de Inserção": Instituto da Segurança Social, I.P. Accessed at March 20, 2015. http://www4.segsocial.pt/documents/10152/15010/rendimento_social_insercao

[3] FEANTSA. 2011 "What is Homelessness?". Accessed at March 20, 2015. http://www.feantsa.org/spip.php?article3381\&lang=en

[4] Globo Universidade. "Entrevista: Maria Cecília Loschiavo relaciona design e sustentabilidade". Last modified 2012. Accessed at March 18 , 2015 .

http://redeglobo.globo.com/globouniversidade/noticia/2012/10/entrevist a-maria-cecilia-loschiavo-relaciona-design-e-sustentabilidade.html

[5] Karnani, Aneel. 2007. Fortune at the Bottom of the Pyramide: A Mirage - How the private sector can help alleviate poverty. SSRN (Social Science Research Network) Accessed at May 30, 2015. http://papers.ssrn.com/sol3/papers.cfm?abstract_id=914518\#\#

[6] Levinson, David. 2004. Encyclopedia of Homelessness vol. 1. USA: Berkshire Publishing Group.

[7] Loschiavo dos Santos, Maria. 2007. "moving beyond homelessness. How design can be an instrument for change." Paper presented at International Association of Societies of Design Research: the Hong Kong Polytechnic University, $12^{\text {th }}$ to $15^{\text {th }}$ November 2007

[8] Lourenço, Paulo. November 2014 "Associações atropelam-se na ajuda aos sem-abrigo". Accessed at March 20, 2015. http://www.jn.pt/paginainicial/nacional/interior.aspx?content_id=42572 13

[9] Pereira, Ana and Oliveira, Mariana. March 2014. "Mais de cinco mil pessoas sem abrigo em Portugal". Accessed at March 20, 2015. http://www.publico.pt/sociedade/noticia/mais-de-cinco-mil-pessoassem-abrigo-em-portugal-1630338 